\title{
Perlindungan Hukum Terhadap Konsumen Pada Perjanjian Pembiayaan dengan Fidusia Tidak Terdaftar
}

\author{
Elis Herlina dan Sri Santi \\ Universitas Islam Nusantara Bandung \\ Jl. Soekarno Hatta No. 530, Bandung, Jawa Barat \\ elisherlina1504@gmail.com
}

Received: 7 Juni 2018; Accepted: 13 Agustus 2018; Published: 5 Nopember 2018

DOI: 10.20885/iustum.vol25.iss2.art4

\begin{abstract}
Fiduciary guarantee shall be registered, so that it has execution order, but sometimes fiduciary guarantee is accepted even if it is not registered. The problem in this study was how is the legal protection for consumers in a fiduciary agreement that is made without a notarial deed and is not registered at the Fiduciary Registration Office seen from Law Number 42 of 1999 concerning Fiduciary Guarantee and Law Number 8 of 1999 concerning Consumer Protection. This was a normative legal research. The results of the study concluded that the legal protection of consumers in a financing agreement with an unregistered fiduciary guarantee is that the principal (someone hiring fiduciary agent) can sue for compensation against the fiduciary agent on the basis of unlawful acts as stipulated in Article 1365 of the Civil Code. In addition, in the event of a crime, a person can be sued by Article 368 of the Criminal Code. Financing agreements with fiduciary guarantees shall contain clauses in accordance with the Consumer Protection Law because regarding this violation, business actors are punishable with maximum imprisonment of 5 (five) years or a maximum fine of IDR 2,000,000,000.00.
\end{abstract}

Keywords: Legal protection; consumers; notarial deed; fiduciary

Abstrak

Pembebanan jaminan fidusia harus didaftarkan, sehingga mempunyai kekuatan eksekutorial, namun masih terdapat pengambilan jaminan fidusia meskipun tidak didaftarkan. Permasalahan dalam penelitian ini adalah bagaimana perlindungan hukum terhadap konsumen pada perjanjian fidusia yang tidak dibuat dengan akta notaris dan tidak didaftarkan di Kantor Pendaftaran Fidusia ditinjau dari Undang-Undang Nomor 42 Tahun 1999 tentang Jaminan Fidusia dan Undang-Undang Nomor 8 Tahun 1999 tentang Perlindungan Konsumen. Penelitian ini merupakan penelitian yuridis normatif. Hasil penelitian menyimpulkan bahwa perlindungan hukum terhadap konsumen pada perjanjian pembiayaan dengan jaminan fidusia yang tidak terdaftar adalah bahwa pemberi fidusia dapat menggugat ganti rugi terhadap penerima fidusia atas dasar perbuatan melawan hukum sebagaimana diatur dalam Pasal 1365 Kitab Undang-Undang Hukum Perdata. Selain itu, apabila terjadi tindak kekerasan dapat dituntut dengan Pasal 368 KUHP. Perjanjian pembiayaan dengan jaminan fidusia harus memuat klausul-klausul yang sesuai dengan Undang-Undang Perlindungan Konsumen, karena terhadap pelanggaran ini, pelaku usaha diancam dengan pidana penjara paling lama 5 (lima) tahun atau pidana denda paling banyak Rp. 2.000.000.000,00.

Kata-kata Kunci : Perlindungan hukum; konsumen; akte notaris; fidusia 


\section{Pendahuluan}

Masyarakat adil dan makmur berdasarkan Pancasila dan Undang-Undang Dasar Negara Republik Indonesia Tahun 1945 dapat dicapai dengan pembangunan ekonomi dan diperlukan dana yang besar untuk pembangunan yang berkesinambungan yang dilakukan baik oleh pemerintah maupun masyarakat perseorangan atau badan hukum. Kebutuhan terhadap pendanaan meningkat seiring dengan peningkatan pembangunan. Dana tersebut diperoleh melalui kegiatan pinjam meminjam. ${ }^{1}$

Untuk menggerakan roda perekonomian diperlukan dana yang besar. Dalam kehidupan masyarakat, di satu sisi terdapat kelompok yang mempunyai dana yang lebih tetapi tidak mampu mengusahakannya, di sisi lain terdapat kelompok yang sedikit memiliki atau sama sekali tidak memiliki dana, tetapi mempunyai kemampuan untuk berusaha. Untuk itu diperlukan perantara selaku kreditur sebagai penyedia dana bagi debitur. Oleh karena itu, dalam masyarakat terdapat pemberian kredit atau perjanjian utang piutang.

Salah satu aktivitas dalam dunia perbankan atau lembaga keuangan lainnya sebagai lembaga keuangan penghimpun dana dari masyarakat adalah pemberian kredit, tetapi hal ini mengandung resiko. Karena itu, untuk keamanan pemberian kredit diperlukan suatu lembaga jaminan. Kreditur berhak untuk menuntut piutangnya terhadap harta kekayaan debitur yang dijaminkan, jika debitur tidak memenuhi prestasinya secara sukarela dengan cara melakukan penjualan benda yang dijaminkan dan hasilnya untuk pemenuhan hutang debitur. ${ }^{2}$ Jika debitur wanprestasi, maka pihak kreditur akan sulit mendapatkan pelunasan pinjamannya dari pihak debitur, bila dalam perjanjian tersebut tidak ada lembaga jaminan. Bank sebagai kreditur lebih menyukai perjanjian jaminan kebendaan, karena akan memberikan hak yang didahulukan (hak preferen).

Saat ini dalam perjanjian kredit banyak diterapkan lembaga jaminan hipotik atau hak tanggungan, gadai dan jaminan fidusia. Bila obyek jaminan atau agunannya benda tetap (benda tidak bergerak), maka digunakan hipotik atau hak

1 Penjelasan Undang-Undang Republik Indonesia Nomor 42 Tahun 1999 tentang Jaminan Fidusia

2 Sofwan, Sri Soedewi Masjchoen, Hukum Jaminan di Indonesia Pokok-Pokok. Hukum Jaminan Perorangan, Liberty Offset, Yogyakarta, 1980, hlm. 
tanggungan, sedangkan gadai atau jaminan fidusia digunakan jika obyek agunannya benda bergerak. Fidusia dalam praktek perbankan sangat populer dan digemari, karena dapat memenuhi kebutuhan masyarakat, khususnya perusahaan kecil dan menengah, karena tidak memberatkan dan sangat membantu usaha debitur, sehingga dapat memberikan manfaat ganda kehadirannya. Untuk keperluan usahanya sehari-hari, penerima kredit masih dapat menguasai barang jaminan dan prosedur pengikatan fidusia lebih praktis dugunakan oleh pihak bank atau lembaga keuangan lainnya, sehingga untuk penyimpanan barang jaminan tidak perlu menyediakan tempat khusus seperti pada lembaga gadai (pand). ${ }^{3}$

Bank pada perjanjian kredit dengan memakai jaminan fidusia harus bertindak sangat hati-hati, terutama mengenai bonafiditas calon debitur, karena pada jaminan fidusia, debitur tetap menguasai barang-barang bergerak yang dijaminkan tersebut, sehingga keberhasilan atau kegagalan bentuk jaminan fidusia itu tergantung pada itikad baik dan bonafiditas pihak debitur. ${ }^{4}$

Undang-Undang Nomor 42 Tahun 1999 tentang Jaminan Fidusia mengatur jaminan fidusia yang memuat ketentuan-ketentuan pada saat melakukan perjanjian jaminan fidusia, antara lain kewajiban mendaftarkan obyek fidusia di Kantor Pendaftaran Fidusia (Pasal 11 ayat (1) jo. Pasal 12 ayat (1) Undang-Undang Nomor 42 Tahun 1999). Kantor Pendaftaran Fidusia kemudian mengeluarkan Sertifikat Jaminan Fidusia dengan irah-irah "DEMI KEADILAN BERDASARKAN KETUHANAN YANG MAHA ESA" yang mempunyai kekuatan eksekutorial seperti suatu keputusan Pengadilan yang telah berkekuatan hukum yang tetap. ${ }^{5}$ Pendaftaran jaminan fidusia memberikan hak yang didahulukan (droit de preference) kepada penerima fidusia terhadap kreditor lain. Selain itu, pendaftaran jaminan fidusia dimaksudkan untuk memberikan kepastian hukum bagi para pihak, baik bagi pemberi fidusia maupun bagi penerima fidusia, sehingga dapat memberikan perlindungan hukum terhadap kreditur (penerima fidusia) dan pihak

${ }^{3}$ Sri Soedewi Mascjhoen Sofwan, Beberapa Masalab Pelaksanaan Lembaga Jaminan Khususnya Fiducia di dalam Praktek dan Pelaksanaannya di Indonesia, Fakultas Hukum Universitas Gadjah Mada, Yogyakarta, 1977, hlm. 75.

${ }^{4} \mathrm{Ibid}$, hlm. 71.

5 J. Satrio, Hukum Jaminan Hak Jaminan Kebendaan, PT. Citra Aditya Bakti, Bandung, 2007, hlm. 198. 
ketiga lainnya. ${ }^{6}$ Undang-Undang Nomor 42 Tahun 1999 tentang Jaminan Fidusia ditetapkan dengan pertimbangan bahwa fidusia dinilai sebagai pemberian fasilitas kemudahan bagi dunia usaha agar lebih berkembang, karena benda yang dijaminkan melalui fidusia dapat tetap dipergunakan oleh pemilik benda untuk modal usahanya. ${ }^{7}$ Mengenai pendaftaran ini juga diatur dalam Pasal 1 ayat (1) jo. Pasal 2 Peraturan Menteri Keuangan Nomor 130/PMK.010/2012 tentang Pendaftaran Jaminan Fidusia Bagi Perusahaan Pembiayaan yang Melakukan Pembiayaan Konsumen Untuk Kendaraan Bermotor Dengan Pembebanan Jaminan Fidusia. Pasal 3 Permenkeu No. 130/2012 menyatakan bahwa perusahaan pembiayaan dilarang melakukan penarikan benda jaminan fidusia berupa kendaraan bermotor apabila Kantor Pendaftaran Fidusia belum menerbitkan sertifikat jaminan fidusia dan menyerahkannya kepada perusahaan pembiayaan. Namun demikian, pada prakteknya masih terdapat jaminan fidusia yang tidak didaftarkan. ${ }^{8}$ Saat ini terdapat fenomena pengambilan benda jaminan oleh penerima fidusia apabila pemberi fidusia tidak melaksanakan kewajibannya sesuai dengan yang diperjanjikan, meskipun angsurannya hanya tinggal beberapa kali dan perjanjian tersebut tidak dibuat dengan akta notaris serta jaminan fidusia tidak didaftarkan, seperti halnya antara lain terjadi di Pekanbaru pada kasus antara PT. Capella Multidana dengan Ade Sulista, setelah membayar angsuran sebanyak 17 kali, Ade Sulista terlambat membayar angsuran dan pihak PT Capella melakukan eksekusi atas mobil yang dijadikan jaminan fidusia tanpa adanya sertifikat jaminan fidusia. ${ }^{9}$ Kasus lainnya, pelaksanaan jaminan fidusia di PT. BPR Arthaprima Danajasa tidak dituangkan dalam perjanjian tersendiri, melainkan hanya dituangkan di dalam perjanjian kredit dan kuasa menjual yang diwaarmerking berupa surat kuasa dengan hak substitusi, berarti jaminan fidusia tersebut tidak didaftarkan ke Kantor Fidusia sesuai ketentuan Pasal 11 UUJF. ${ }^{10}$ Hal tersebut

\footnotetext{
${ }^{6}$ Ida Ayu Made Widyari, I Nyoman Sirtha, I Made Sarjana, Akibat Hukum Pendaftaran Jaminan Fidusia Dalam Sistem Online, Acta Comitas (2017) 2, hlm. 268-276.

7 Rizka, "Fidusia Dalam Lingkup Hukum Jaminan Dilihat Dari Sudut Pandangan Islam”, artikel dalam Jurnal EduTech Vol.2 No. 1 Maret 2016, hlm. 72.

${ }^{8}$ H. Tan Kamelo, Hukum Jaminan Fidusia Suatu Kebutuhan Yang Didambakan, Alumni, Bandung, 2006, hlm. 213.

${ }_{9}^{9}$ Muhammad Ikhsan Putra, "Eksekusi Terhadap Benda Jaminan Fidusia Yang Tidak Didaftarkan Pada PT. Capella Multidana”, artikel dalam JOM Fakultas Hukum Volume III Nomor I Februari 2016, hlm. 3

${ }^{10}$ Ilda Agnes, Eksekusi Jaminan Fidusia Yang Tidak. Didaftarkan Ke Kantor Pendaftaran Fidusia (Studi Kasus Di PT. BPR. Arthaprima Danajasa Bekasi), eprints.undip.ac.id/1776/1/ILDA_AGNES, diakses 2 September 2018.
} 
merupakan pelanggaran terhadap Undang-Undang Jaminan Fidusia dan pelanggaran atas hak debitur yang perlu mendapat perlindungan.

\section{Rumusan Masalah}

Bagaimana perlindungan hukum terhadap konsumen pada perjanjian fidusia yang tidak dibuat dengan akta notaris dan tidak didaftarkan di Kantor Pendaftaran Fidusia ditinjau dari Undang-Undang Nomor 42 Tahun 1999 tentang Jaminan Fidusia dan Undang-Undang Nomor 8 Tahun 1999 tentang Perlindungan Konsumen?

\section{Tujuan Penelitian}

Adapun tujuan penelitian ini adalah untuk mengetahui, memahami dan menganalisis perlindungan hukum terhadap konsumen pada perjanjian fidusia yang tidak dibuat dengan akta notaris dan tidak didaftarkan di Kantor Pendaftaran Fidusia ditinjau dari Undang-Undang Nomor 42 Tahun 1999 tentang Jaminan Fidusia dan Undang-Undang Nomor 42 Tahun 1999 tentang Perlindungan Konsumen.

\section{Metode Penelitian}

Penelitian ini menggunakan metode pendekatan yuridis normatif, yaitu penelitian dengan menggunakan data sekunder atau data kepustakaan ${ }^{11}$ dan bersifat deskriptif analitis, yaitu menyampaikan gambaran mengenai fakta-fakta yang ada ditunjang dengan ketentuan-ketentuan yang berlaku dan diterapkan. ${ }^{12}$ Metode pendekatan yang digunakan dalam penelitian ini adalah pendekatan perundang-undangan (statute approach), yaitu dengan mengkaji dan menganalisis norma atau materi muatan dalam peraturan perundang-undangan untuk menganalisis permasalahan dalam penelitian. Sebagai data penunjang dilakukan wawancara dengan pihak yang terkait. Kemudian data yang diperoleh dianalisis dengan menggunakan metode deskriptif kualitatif. ${ }^{13}$

\footnotetext{
10

${ }^{11}$ Ronny Hanitijo Soemitro, Metodologi Penelitian Hukum dan Juritmetri, Ghalia Indonesia, Jakarta, 1990, hlm.

12 Soerjono Soekanto, Pengantar Penelitian Hukum, Universitas Indonesia Pers, Jakarta, 1986, hlm. 86.

${ }_{13}$ Maria S.W. Sumardjono, Pedoman Pembuatan Usulan Penelitian, Fakultas Hukum UGM, Yogyakarta, 1989, hlm. 24-25.
} 


\section{Hasil Penelitian dan Pembahasan}

\section{Perlindungan Hukum Terhadap Konsumen pada Perjanjian Fidusia yang Tidak Dibuat dengan Akta Notaris dan Tidak Didaftarkan di Kantor Pendaftaran Fidusia}

Fidusia menurut asal katanya berasal dari kata "fides" yang berarti kepercayaan. Oleh karena itu, hubungan (hukum) antara debitur (pemberi fidusia) dan kreditur (penerima fidusia) adalah hubungan hukum atas dasar kepercayaan. Pemberi fidusia percaya bahwa setelah dilunasi hutangnya, maka penerima fidusia akan mengembalikan hak milik atas barang yang telah diserahkan. Penerima fidusia juga percaya bahwa barang jaminan yang berada dalam kekuasaan pemberi fidusia tidak akan disalahgunakan. ${ }^{14}$

Kata "fidusia" menurut Mahadi berasal dari bahasa Latin yang merupakan kata benda dan mempunyai arti kepercayaan terhadap seseorang atau sesuatu, pengharapan yang besar. Demikian juga terdapat kata "fido" berupa kata kerja, yang mempunyai arti mempercayai seseorang atau sesuatu. ${ }^{15}$ Dalam fidusia menurut Subekti terkandung kata "fides" berarti kepercayaan, pihak berpiutang diberi kepercayaan oleh pihak yang berhutang untuk memiliki barangnya itu sebagai jaminan saja. ${ }^{16}$ Subekti dalam bukunya yang lain menjelaskan bahwa arti kata "fiduciair" adalah suatu pihak memberikan kepercayaan secara timbal balik kepada yang lain, tampak keluar bahwa sebagai pemindahan milik, padahal (ke dalam, intern) hanya sebagai jaminan saja untuk suatu hutang. ${ }^{17}$

Pasal 1 sub 1 Undang-Undang Jaminan Fidusia mengatur bahwa fidusia adalah pengalihan hak kepemilikan suatu benda atas dasar kepercayaan dengan ketentuan bahwa benda yang hak kepemilikannya dialihkan tersebut tetap dalam penguasaan pemilik benda. Terdapat beberapa ciri dalam perumusan tersebut, yaitu pengalihan hak kepemilikan suatu benda; atas dasar kepercayaan; dan benda itu tetap dalam penguasaan pemilik benda. ${ }^{18}$

\footnotetext{
${ }^{14}$ Gunawan Widjaja \& Ahmad Yani, Jaminan Fidusia, PT. Raja Grafindo Persada, 2007, hlm. 119.

${ }^{15}$ Mahadi, dalam Tan Kamelo, Hukum..., Op. Cit., hlm. 39.

16 Subekti, Pokok-Pokok. Hukum Perdata, Intermasa, Jakarta, 1982, hlm. 82.

17 Subekti, Jaminan-Jaminan untuk Pemberian Kredit Menurut Hukum Indonesia, Alumni, Bandung, 1982, hlm.

18 J. Satrio, Hukum..., Op. Cit., hlm. 181.
} 76. 
Oleh karena itu, pemilik menyerahkan hak milik atas benda yang diberikan sebagai jaminan kepada kreditur penerima jaminan, sehingga kreditur penerima jaminan mempunyai hak milik atas benda jaminan. Pengalihan hak kepemilikan tersebut dilakukan dengan cara constitutum possessorium (verklaring van houderschap). ${ }^{19}$ Dengan kata lain, pengalihan hak kepemillikan atas suatu benda dengan melanjutkan penguasaan atas benda tersebut untuk kepentingan penerima fidusia. Secara fisik benda tersebut tetap dikuasai oleh pemberi jaminan, namun hak yuridisnya saja yang diserahkan atas benda tersebut, pemberi jaminan tetap mempunyai hak pemanfaatan.

Pengalihan hak kepemilikan pada jaminan fidusia semata-mata sebagai jaminan saja bagi pelunasan utang, bukan untuk dimiliki seterusnya oleh penerima fidusia. Pasal 33 Undang-Undang Jaminan Fidusia mengatur bahwa setiap janji yang memberikan kewenangan kepada penerima fidusia untuk memiliki benda yang menjadi objek jaminan fidusia apabila debitur cidera janji, akan batal demi hukum.

Kata-kata "atas dasar kepercayaan" boleh ditafsirkan bahwa kreditur dengan penyerahan itu tidak benar-benar menjadi pemilik atas benda jaminan, karena pemberi jaminan percaya bila hutang nanti dilunasi, maka pemberi jaminan akan kembali menerima hak milik atas benda jaminan tersebut. ${ }^{20}$

Pasal 1 butir 2 Undang-Undang Jaminan Fidusia mengatur bahwa jaminan fidusia adalah hak jaminan atas benda bergerak, baik yang berwujud maupun yang tidak berwujud dan benda tidak bergerak, khususnya bangunan yang tidak dapat dibebani hak tanggungan sebagaimana dimaksud dalam Undang-Undang Nomor 4 Tahun 1996 tentang Hak Tanggungan yang tetap berada dalam penguasaan pemberi fidusia, sebagai agunan bagi pelunasan utang tertentu, yang memberikan kedudukan yang diutamakan kepada penerima fidusia terhadap kreditor lainnya.

Oleh karena itu, Undang-Undang Jaminan Fidusia menyatakan bahwa jaminan fidusia adalah agunan atas kebendaan atau jaminan kebendaan (zakelijke zekerheid, security right in rem) yang memberikan kedudukan yang diutamakan

\footnotetext{
${ }^{19}$ Gunawan Widjaja, Jaminan..., Op. Cit., hlm. 136.

${ }^{20}$ J. Satrio, Hukum..., Op. Cit., hlm. 182.
} 
kepada penerima fidusia, yaitu hak yang didahulukan terhadap kreditur lainnya.. ${ }^{21}$ Pasal 4 Undang-Undang Jaminan Fidusia menentukan bahwa jaminan fidusia merupakan perjanjian ikutan dari suatu perjanjian pokok yang menimbulkan kewajiban bagi para pihak untuk memenuhi suatu prestasi. Perjanjian jaminan fidusia sebagai suatu perjanjian ikutan atau assesoir, bersifat sebagai berikut:22

a. Sifat ketergantungannya terhadap perjanjian pokok;

b. Keabsahannya semata-mata ditentukan oleh sah tidaknya perjanjian pokok;

c. Sebagai perjanjian bersyarat, maka hanya dapat dilaksanakan jika ketentuan yang disyaratkan dalam perjanjian pokok telah atau tidak dipenuhi.

Hal ini terlihat dalam Pasal 19 ayat (1) Undang-Undang Fidusia: "pengalihan hak atas piutang yang dijamin dengan fidusia mengakibatkan beralihnya demi hukum segala hak dan kewajiban penerima fidusia kepada kreditor baru, serta Pasal 25 Undang-Undang Fidusia yang menyatakan bahwa jaminan fidusia hapus, jika hutang yang dijamin dengan fidusia hapus. Dengan kata lain, jaminan fidusia bersifat accessoir, hal ini berarti jaminan fidusia tidak berdiri sendiri tetapi keberadaan atau hapusnya tergantung pada perjanjian pokoknya. ${ }^{23}$

Tagihan kreditur penerima fidusia merupakan tagihan preferen, karena dalam jaminan fidusia dianut prinsip droit de preference, yaitu pengambilan pelunasan atas hasil eksekusi dari benda jaminan fidusia lebih didahulukan, dengan kata lain, tagihan tersebut merupakan tagihan preferen. Hal ini disimpulkan dari ketentuan Pasal 27 Undang-Undang Fidusia, yang menyatakan bahwa penerima fidusia mempunyai hak yang didahulukan terhadap kreditur lain. ${ }^{24}$ Walaupun pemberi fidusia dinyatakan pailit atau dilikuidasi, tidak menghapuskan hak yang didahulukan dari penerima fidusia, karena harta pailit tidak meliputi objek jaminan pemberi fidusia. Oleh karena itu, penerima fidusia termasuk kelompok kreditur separatis. Sesuai ketentuan Pasal 28 Undang-Undang Fidusia, prinsip ini berlaku sejak tanggal pendaftarannya pada Kantor Pendaftaran Fidusia, sehingga berlaku adagium first registered, first secured. ${ }^{25}$

${ }^{21}$ Gunawan Widjaja \& Ahmad Yani, Jaminan..., Op. Cit., hlm. 131.

22 Ibid., hlm. 131.

${ }^{23}$ Faranisa Yona Ramadhani, Muhamamad Fakih, Dita Febrianto, "Kedudukan Akta Otentik yang Dibuat oleh Notaris pada Pembuatan Akta Jaminan Fidusia”, artikel dalam Pactum Law Journal, Volume 1 No. 1, 2017, hlm, hlm. 4

${ }^{24}$ J. Satrio, Hukum..., Op. Cit., hlm.190.

${ }_{25}$ Gunawan Widjaja \& Ahmad Yani, Jaminan..., Op. Cit., hlm. 132. 
Pengakuan atas prinsip droit de suite mengakibatkan jaminan fidusia tetap mengikuti benda yang menjadi objek jaminan fidusia dalam tangan siapapun benda tersebut berada, ${ }^{26}$ kecuali bila objek jaminan fidusia tersebut merupakan benda persediaan. Pasal 21 Undang-Undang Jaminan Fidusia menyatakan bahwa pemberi fidusia dapat mengalihkan benda persediaan yang menjadi objek jaminan fidusia dengan cara dan prosedur yang lazim dilakukan dalam usaha perdagangan, namun bila benda yang menjadi objek jaminan fidusia itu tidak merupakan benda persediaan, maka Pasal 23 ayat (2) Undang-Undang Jaminan Fidusia secara tegas melarang pemberi fidusia untuk mengalihkan, menggadaikan, atau menyewakan kepada pihak lain, kecuali dengan persetujuan tertulis terlebih dahulu dari penerima fidusia. Pelanggaran terhadap larangan tersebut diancam dengan pidana penjara paling lama 2 tahun dan denda paling banyak Rp. $50.000 .000,00$.

Objek jaminan fidusia adalah benda berwujud atau tidak berwujud, terdaftar ataupun tidak terdaftar, juga benda bergerak ataupun tidak bergerak yang tidak dapat dibebani dengan hak tanggungan seperti yang dinyatakan dalam UndangUndang Nomor 4 Tahun 1996 tentang Hak Tanggungan atau Hipotik. Hal ini tercantum dalam Pasal 1 butir 2 dan 4, serta Pasal 3 Undang-Undang Jaminan Fidusia. $^{27}$

Pasal 5 ayat (1) Undang-Undang Jaminan Fidusia menyebutkan "Pembebanan benda jaminan fidusia dibuat dengan akta notaris dalam bahasa Indonesia dan merupakan akta Jaminan Fidusia".

Menurut Pasal 11 Undang-Undang Jaminan Fidusia, objek jaminan fidusia harus didaftarkan pada Kantor Pendaftaran Fidusia di tempat kedudukan pemberi fidusia yang meliputi benda, baik yang berada di dalam maupun di luar wilayah Negara Republik Indonesia. Hal ini untuk memenuhi asas publisitas. Pelaksanaan pendaftaran tersebut diatur dalam Peraturan Pemerintah Nomor 21 Tahun 2015

${ }^{26}$ Ibid., hlm. 133.

${ }^{27}$ Ibid., hlm. 141. 
tentang Tata Cara Pendaftaran Jaminan Fidusia dan Biaya Pembuatan Akta Jaminan Fidusia. 28

Penerima fidusia atau kuasanya melakukan permohonan pendaftaran jaminan fidusia ke Kantor Pendaftaran Fidusia, kemudian dicatat dalam Buku Daftar Fidusia. Tanggal penerimaan permohonan pendaftaran dianggap sebagai saat lahirnya jaminan fidusia. Oleh karena itu, pendaftaran sebagai perbuatan konstitutif yang melahirkan jaminan fidusia. ${ }^{29}$

Kemudian Kantor Pendaftaran Fidusia menerbitkan Sertifikat Jaminan Fidusia yang merupakan bukti bagi kreditur sebagai pemegang jaminan fidusia. Sertifikat tersebut mencantumkankata-kata “DEMI KEADILAN BERDASARKAN KETUHANAN YANG MAHA ESA" sebagaimana ditegaskan dalam Pasal 14 ayat (1). Sertifikat Jaminan Fidusia memiliki kekuatan eksekutorial seperti putusan pengadilan yang mempunyai kekuatan hukum yang tetap, sehingga dapat langsung dieksekusi tidak melalui proses persidangan serta bersifat final dan mengikat kedua belah pihak.

Dalam rangka meningkatkan pelayanan kepada masyarakat, pada 2013 pemerintah mengeluarkan Peraturan Menteri Hukum dan Hak Asasi Manusia Republik Indonesia Nomor 9 Tahun 2013 tentang Pemberlakuan Pendaftaran Jaminan Fidusia Secara Elektronik dan Peraturan Menteri Hukum dan Hak Asasi Manusia Republik Indonesia Nomor 10 Tahun 2013 tentang Tata Cara Pendaftaran Jaminan Fidusia Secara Elektronik. Pasal 3 Peraturan Menteri Hukum dan Hak Asasi Manusia Nomor 9 Tahun 2013 menyatakan bahwa pendaftaran jaminan fidusia secara elektronik dapat dilakukan melalui kios pelayanan pendaftaran fidusia secara elektronik di seluruh Kantor Pendaftaran Fidusia. Kantor pendaftaran fidusia secara elektronik adalah kantor notaris dan hanya notaris yang dapat mengakses website www.sisminbakum.go.id dengan tata cara sebagai berikut: 30

(1). Pendaftaran permohonan Jaminan Fidusia secara elektronik dilakukan dengan mengisi formulir aplikasi.

28 Arista Setyorini, Agus Muwarto, "Akibat Hukum Perjanjian Pembiayaan Konsumen dengan Pembebanan Jaminan Fidusia yang Tidak Didaftarkan”, artikel dalam Mimbar Keadilan Jurnal Ilmu Hukum, Agustus 2017, hlm.124.

${ }^{29}$ Gunawan Widjaja \& Ahmad Yani, Jaminan..., Op. Cit., hlm. 148.

${ }^{30}$ Ida Ayu Made Widyari, Akibat..., Op. Cit., hlm. 272. 
(2). Pengisian formulir aplikasi sebagaimana dimaksud pada ayat (1) meliputi:
a. Identitas pemohon;
b. Identitas pemberi fidusia;
c. Identitas penerima fidusia;
d. Akta jaminan fidusia;
e. Perjanjian pokok;
f. Nilai penjaminan; dan
g. Nilai benda yang menjadi obyek Jaminan Fidusia

(3). Pemohon mencetak bukti pendaftaran setelah selesai melakukan pengisian formulir aplikasi.

(4). Bukti pendaftaran sebagaimana dimaksud pada ayat (3) memuat :
a. nomor pendaftaran;
b. tanggal pengisian aplikasi;
c. nama pemohon;
d. nama Kantor Pendaftaran Fidusia;
e. jenis permohonan; dan
f. biaya pendaftaran permohonan Jaminan Fidusia sesuai dengan ketentuan peraturan perundang-undangan.

(5). Berdasarkan bukti pendaftaran sebagaimana dimaksud pada ayat (4), pemohon melakukan pembayaran biaya pendaftaran permohonan Jaminan Fidusia melalui Bank Persepsi.

(6). Setelah melakukan pembayaran sebagaimana dimaksud pada ayat (5), pemohon mencetak sertifikat Jaminan Fidusia yang telah ditandatangani secara elektronik oleh Pejabat Pendaftaran Jaminan Fidusia.

Pasal 25 Undang-Undang Jaminan Fidusia menyebutkkan bahwa jaminan fidusia hapus karena:

a. Hapusnya utang yang dijamin dengan fidusia;

b. Pelepasan hak atas jaminan fidusia oleh penerima fidusia; atau

c. Musnahnya benda yang menjadi objek jaminan fidusia".

Karena jaminan fidusia bersifat assesoir, maka jika utang piutang yang menjadi perjanjian pokoknya hapus, maka jaminan fidusia juga menjadi hapus, namun apabila objek jaminan fidusia diasuransikan, klaim asuransi tidak hapus dan berfungsi sebagai pengganti objek jaminan fidusia. ${ }^{31}$

Penghapusan jaminan fidusia harus diberitahukan kepada Kantor Pendaftaran Fidusia oleh penerima fidusia dengan melampirkan alasannya agar terdapat kepastian untuk Kantor Pendaftaran Fidusia pada waktu mencoret pencatatan jaminan fidusia dari Buku Daftar Fidusia, kemudian akan diterbitkan

${ }^{31}$ Ibid., hlm. 157. 
surat keterangan pernyataan bahwa Sertifikat Jaminan Fidusia itu sudah tidak berlaku lagi. ${ }^{32}$

Apabila pemberi fidusia wanprestasi, akan dilakukan eksekusi terhadap jaminan fidusia. Pasal 29 Undang-Undang Jaminan Fidusia menjelaskan, eksekusi dapat dilakukan dengan cara:

a. Pelaksanaan title eksekutorial oleh penerima fidusia;

b. Penjualan benda yang menjadi objek jaminan fidusia atas kekuasaan penerima fidusia sendiri melalui pelelangan umum serta mengambil pelunasan piutangnya dari hasil penjualan;

c. Penjualan di bawah tangan yang dilakukan berdasarkan kesepakatan pemberi dan penerima fidusia, jika dengan cara demikian dapat diperoleh harga tertinggi yang menguntungkan para pihak.

Pada Pasal 30 Undang-Undang Jaminan Fidusia menjelaskan Pemberi fidusia wajib menyerahkan benda yang menjadi objek Jaminan Fidusia dalam rangka pelaksanaan eksekusi jaminan fidusia. Bila objek jaminan fidusia tidak diserahkan oleh pemberi fidusia, juga dapat meminta bantuan pihak yang berwenang jika diperlukan. Pasal 32 menjelaskan "Setiap janji untuk melaksanakan eksekusi terhadap benda yang menjadi objek jaminan fidusia dengan cara yang bertentangan dengan ketentuan sebagaimana dimaksud dalam Pasal 31, batal demi hukum". Pada Pasal 33 dijelaskan setiap janji yang memberi kewenangan kepada penerima fidusia untuk memiliki benda yang menjadi objek jaminan fidusia apabila debitor cidera janji, batal demi hukum. Hal ini bentuk perlindungan terhadap pemberi fidusia, bila nilai objeknya lebih besar daripada utangnya. ${ }^{33}$

Kenyataannya di masyarakat, dalam melaksanakan perjanjian pembiayaan oleh lembaga pembiayaan dicantumkan kata-kata dijaminkan secara fidusia, namun tidak dibuat dalam akta notaris dan tidak didaftarkan di Kantor Pendaftaran Fidusia, sehingga tidak mempunyai sertifikat. Sebetulnya penerima fidusia dilindungi dengan pembuatan sertifikat tersebut apabila pemberi fidusia tidak memenuhi kewajibannya sesuai dengan apa yang diperjanjika. Apabila jaminan fidusia tidak didaftarkan sesuai ketentuan Undang-Undang Nomor 42 Tahun 1999 dan aturan pelaksanaannya, maka akta perjanjian fidusia tersebut 
termasuk katagori perjanjian di bawah tangan dan dibutuhkan campur tangan pihak peradilan dalam penyelesaiannya dan proses eksekusi harus dilakukan dengan cara pengajuan kepada pengadilan setelah putusannya mempunyai kekuatan hukum yang tetap. Pada proses eksekusi terhadap benda yang menjadi objek jaminan fidusia, para pihak harus memperhatikan hak debitur yang melekat pada objek benda yang menjadi jaminan pinjaman tersebut, karena debitur telah melakukan prestasinya dengan membayar beberapa kali angsuran, sehingga pada benda yang menjadi objek jaminan fidusia telah ada sebagian hak yang dimiliki oleh debitur, sebagian lainnya milik kreditur. Jika eksekusi dilakukan secara paksa melalui jasa debt collector, maka hal ini melanggar hukum dan pelanggaran tersebut dikatagorikan sebagai perbuatan melawan hukum yang diatur dalam Pasal 1365 Kitab Undang-Undang Hukum Perdata, sehingga debitur dapat mengajukan gugatan ganti rugi melalui pengadilan atas perbuatan kreditur tersebut. ${ }^{34}$ Dengan kata lain, hak preferen kreditur hilang, karena hanya sebagai kreditur konkuren dan untuk eksekusi jaminan fidusia terhadap debitur yang wanprestasi harus melalui gugatan biasa yang diajukan ke Pengadilan Negeri yang berwenang. ${ }^{35}$

Selain itu, tindakan sewenang-wenang yang dilakukan oleh kreditur melalui debt collector atau penagih hutang yang melakukan pemaksaan mengambil barang secara sepihak, padahal diketahui dalam barang tersebut sebagian atau seluruhnya milik orang lain, maka tindakan tersebut dapat dikatagorikan perbuatan yang melanggar hukum pidana, khususnya melanggar Pasal 368 KUH Pidana yang berbunyi:

“Barang siapa dengan maksud untuk menguntungkan diri sendiri atau orang lain secara melawan hukum, memaksa seseorang dengan kekerasan untuk memberikan barang sesuatu, yang seluruhnya atau atau sebagian adalah kepunyaan orang itu atau orang lain, atau supaya membuat hutang maupun menghapuskan piutang, diancam karena pemerasan dengan pidana penjara paling lama sembilan tahun". ${ }^{36}$

34 Muhammad Hilmi Akhsin, Anis Mashdurohatun, "Akibat Hukum Jaminan Fidusia Yang Tidak Didaftarkan Menurut UU Nomor 42 Tahun 1999”, artikel dalam Jurnal Akta Vol. 4 No. 3 September 2017, hlm. 496-497.

${ }^{35}$ Arista Setyorini, Agus Muwarto, Akibat..., Op. Cit., hlm. 131.

36 Muhammad Hilmi Akhsin, Anis Mashdurohatun, Op. Cit., hlm. 497. 
Perlindungan Hukum Terhadap Konsumen Pada Perjanjian Fidusia Yang Tidak Dibuat Dengan Akta Notaris Dan Tidak Didaftarkan Di Kantor Pendaftaran Fidusia Ditinjau Dari Undang-Undang Nomor 8 Tahun 1999

Konsumen dan pelaku usaha mempunyai hubungan yang sejajar, karena saling membutuhkan. Berbagai kemudahan ditawarkan oleh pelaku usaha untuk membantu konsumen yang tidak memiliki dana yang cukup untuk mendapatkan barang yang diperlukan konsumen melalui lembaga pembiayaan yang dituangkan dalam bentuk perjanjian pembiayaan dengan hak milik secara fidusia. Perjanjian pembiayaan itu ditandatangani oleh konsumen dengan semacam surat pernyataan bersama dan surat kuasa untuk menarik/mengambil kembali kendaraan. ${ }^{37}$ Pembiayaan ini diberikan dengan perjanjian pemberian kredit kepada konsumen. Permasalahan akan timbul apabila konsumen menunggak pembayaran angsuran, maka perusahaan pembiayaan akan mengambil kembali barang tersebut.

Berkaitan dengan kewajiban penerima fidusia untuk mendaftarkan barang jaminan di Kantor Pendaftaran Fidusia juga tertuang dalam Pasal 1 Peraturan Menteri Keuangan Nomor 130/PMK.010/2012. Pasal 2 Peraturan Menteri tersebut menyebutkan bahwa perusahaan pembiayaan wajib mendaftarkan jaminan fidusia pada Kantor Pendaftaran Fidusia paling lama 30 hari kalender terhitung sejak tanggal perjanjian pembiayaan konsumen. ${ }^{38}$

Menurut Pasal 3 Peraturan Menteri Keuangan No. 130/PMK.010/2012, perusahaan pembiayaan dilarang melakukan penarikan benda jaminan fidusia berupa kendaraan bermotor apabila Kantor Pendaftaran Fidusia belum menerbitkan sertifikat jaminan fidusia dan menyerahkannya kepada perusahaan pembiayaan. 39

Ciri utama dari perjanjian fidusia adalah benda jaminan harus tetap berada dalam penguasaan debitur, jika benda jaminan diserahkan atau dikuasai oleh kreditur, maka perjanjian fidusia tidak sah. Bila debitur pemberi fidusia tidak memenuhi kewajibannya, maka penerima fidusia dapat menarik benda jaminan

${ }^{37}$ Juwita, Leasing Dalam Perspektif Perlindungan Konsumen Menurut Undang-Undang No. 8 Tabun 1999 Tentang Perlindungan Konsumen, jlps.iblam.ac.id/index.php/jurnal-hukum-dan-kebijakan/../63byS.suardi.2016, diakses tanggal 3 Maret 2018.

38 Peraturan Menteri Keuangan Nomor 130/PMK.010/2012.

${ }^{39}$ Ibid 
fidusia untuk dijual guna menutupi utang debitur. ${ }^{40}$ Namun bila penerima fidusia tidak mendaftarkan objek jaminan fidusia, maka penerima fidusia tidak mempunyai hak untuk mengambil benda jaminan tersebut.

Berlakunya pendaftaran sistem online pada pendaftaran jaminan fidusia, maka pendaftaran fidusia hanya dapat dilakukan pada kantor notaris dan oleh notaris. Setelah menginput seluruh data, maka secara otomatis jaminan fidusia telah dicatatkan dengan sistem online dan dapat dicetak sertifikat jaminan fidusia. Adapun pihak yang mencetaknya adalah pemohon pendaftaran itu sendiri di kantor notaris oleh notaris itu sendiri. ${ }^{41}$

Akibat hukum dari perjanjian jaminan fidusia yang tidak terdaftarkan dalam sistem online, yaitu tidak melahirkan perjanjian kebendaan bagi jaminan fidusia tersebut, sehingga karakter kebendaan seperti droit de suite dan hak preferensinya tidak melekat pada kreditur penerima jaminan fidusia. Undang-Undang Nomor 42 Tahun 1999 mensyaratkan bahwa benda yang dibebani jaminan fidusia wajib didaftarkan, sehingga mempunyai hak mendahului (preference) dan mempunyai kekuatan eksekutorial.42

Berkaitan dengan adanya kekuatan eksekutorial terhadap jaminan fidusia yang didaftarkan, pada prakteknya terdapat perusahaan pembiayaan yang tidak mendaftarkan objek jaminan fidusia, namun tetap mengambil benda jaminan tersebut, bahkan dengan tindakan kekerasan. Hal ini tentu sangat merugikan pemberi fidusia sebagai konsumen.

Pasal 1 angka 1 Undang-Undang Nomor 8 Tahun 1999 tentang Perlindungan Konsumen menyebutkan "Perlindungan konsumen adalah segala upaya yang menjamin adanya kepastian hukum untuk memberi perlindungan kepada konsumen". Konsumen berasal dari istilah asing, Inggris consumer dan Belanda consument yang secara harfiah berarti orang atau perusahaan yang membeli barang tertentu atau menggunakan jasa tertentu, atau sesuatu atau seseorang yang

40 Tan Kamelo, Hukum Jaminan Fidusia Suatu Kebutuban Yang Didambakan, Alumni, Bandung, 2006, hlm. 277.

${ }^{41}$ Ida Ayu Made Widyari, Akibat..., Op. Cit., hlm. 273.

42 Ibid., hlm. 276. 
menggunakan suatu persediaan atau sejumlah barang. Juga ada yang mengartikan setiap orang yang menggunakan barang atau jasa. ${ }^{43}$

Pasal 1 angka 2 Undang-Undang Perlindungan Konsumen menyebut "Konsumen adalah setiap orang pemakai barang dan/atau jasa yang tersedia dalam masyarakat, baik bagi kepentingan diri sendiri, keluarga, orang lain, maupun makhluk hidup lain dan tidak untuk diperdagangkan".

Pasal 2 Undang-Undang Perlindungan Konsumen dan penjelasannya menentukan bahwa perlindungan konsumen diselenggarakan berdasarkan 5 asas yang relevan dengan pembangunan nasional, yaitu:44

a. Asas manfaat, maksudnya bahwa segala upaya dalam menyelenggarakan perlindungan konsumen harus memberikan manfaat sebesar-besarnya bagi kepentingan konsumen dan pelaku usaha secara keseluruhan.

b. Asas keadilan, maksudnya agar partisipasi seluruh rakyat dapat diwujudkan secara maksimal dan memberikan kesempatan kepada konsumen dan pelaku usaha untuk memperoleh haknya dan melaksanakan kewajibannya secara adil.

c. Asas keseimbangan, maksudnya untuk memberikan keseimbangan antara kepentingan konsumen, pelaku usaha, dan pemerintah dalam arti materiil dan spiritual.

d. Asas keamanan dan keselamatan konsumen, maksudnya untuk memberikan jaminan atas keamanan dan keselamatan kepada konsumen dalam penggunaan, pemakaian, dan pemanfaatan barang dan/atau jasa yang dikonsumsi atau digunakan.

e. Asas kepastian hukum, maksudnya agar pelaku usaha maupun konsumen menaati hukum dan memperoleh keadilan dalam menyelenggarakan perlindungan konsumen, serta negara menjamin kepastian hukum.

Adapun tujuan dari perlindungan konsumen adalah sebagaimana ditegaskan dalam Pasal 3 Undang-Undang Perlindungan Konsumen, yaitu: ${ }^{45}$

a. Meningkatkan kesadaran, kemampuan, dan kemandirian konsumen untuk melindungi diri;

b. Mengangkat harkat dan martabat konsumen dengan cara menghindarkannya dari ekses negatif pemakaian barang dan/atau jasa;

c. Meningkatkan pemberdayaan konsumen dalam memilih, menentukan, dan menuntut hak-haknya sebagai konsumen;

${ }^{43}$ Abdul Hakim Barkatulah, Hukum Perlindungan Konsumen Kajian Teoritis dan Perkembangan Pemikiran, Nusa Media, 2008, hlm. 7.

44 Ahmadi Miru \& Sutarman Yodo, Hukum Perlindungan Konsumen, Raja Grafindo Persada, Jakarta, 2007, hlm. 25-26.

45 Ibid., hlm. 33. 
d. Menciptakan sistem perlindungan konsumen yang mengandung unsur kepastian hukum dan keterbukaan informasi serta akses untuk mendapatkan informasi;

e. Menumbuhkan kesadaran pelaku usaha mengenai pentingnya perlindungan konsumen, sehingga tumbuh sikap yang jujur dan bertanggung jawab dalam berusaha;

f. Meningkatkan kualitas barang dan/atau jasa yang menjamin kelangsungan usaha produksi barang dan/atau jasa, kesehatan, kenyamanan, keamanan, dan keselamatan konsumen.

Apabila berbicara tentang perlindungan konsumen berarti mempersoalkan jaminan atau kepastian tentang terpenuhinya hak-hak konsumen. ${ }^{46}$ Pasal 4 Undang-Undang Perlindungan Konsumen menyebutkan sejumlah hak konsumen yang mendapat jaminan dan perlindungan dari hukum, yaitu: ${ }^{47}$

a. Hak atas kenyamanan, keamanan dan keselamatan dalam mengonsumsi barang dan/jasa;

b. Hak untuk memilih barang dan/atau jasa serta mendapatkan barang dan/atau jasa tersebut sesuai dengan nilai tukar dan kondisi serta jaminan yang dijanjikan;

c. Hak atas informasi yang benar, jelas dan jujur mengenai kondisi dan jaminan barang dan/atau jasa;

d. Hak untuk didengar pendapat dan keluhannya atas barang dan/atau jasa yang digunakan;

e. Hak untuk mendapatkan advokasi, perlindungan, dan upaya penyelesaian sengketa perlindungan konsumen secara patut;

f. Hak untuk mendapatkan pembinaan dan pendidikan konsumen;

g. Hak untuk diperlakukan atau dilayani secara benar dan jujur serta tidak diskriminatif;

h. Hak untuk mendapatkan kompensasi, ganti rugi, dan/atau penggantian, apabila barang dan/atau jasa yang diterima tidak sesuai dengan perjanjian atau tidak sebagaimana mestinya;

i. Hak-hak yang diatur dalam ketentuan peraturan perundang-undangan lainnya.

Berkaitan dengan eksekusi yang dilakukan oleh debt collector secara sepihak dan jaminan fidusia tersebut tidak didaftarkan di Kantor Pendaftaran Fidusia, maka hal ini tidak sesuai dengan asas perlindungan konsumen tentang keamanan dan keselamatan konsumen serta kepastian hukum sebagaimana diatur dalam Pasal 2 Undang-Undang Nomor 8 Tahun 1999 tentang Perlindungan Konsumen. Di samping itu, juga telah melanggar hak-hak konsumen sebagaimana diatur

\footnotetext{
46 Janus Sidabalok, Hukum Perlindungan Konsumen di Indonesia, Citra Aditya Bakti, 2006, hlm.10.

${ }^{47}$ Ibid., hlm 39.
} 
dalam Pasal 4 Undang-Undang Nomor 8 Tahun 1999 di mana konsumen berhak atas kenyamanan, keamanan dan keselamatan dalam mengkonsumsi barang dan jasa. ${ }^{48}$

Perjanjian pembiayaan dengan penyerahan hak milik secara fidusia dibuat dengan kesepakatan antara perusahaan pembiayaan dengan konsumen. Isi dari perjanjian tersebut berupa klausula-klausula baku yang merupakan ketentuanketentuan atau syarat-syarat yang dibuat secara sepihak oleh perusahaan pembiayaan dan dituangkan dalam suatu dokumen perjanjian yang mengikat serta wajib dipenuhi oleh konsumen, sehingga posisi konsumen lemah karena harus mengikuti semua ketentuan yang telah dibuat oleh perusahaan pembiayaan. Oleh karena itu, diperlukan perlindungan terhadap konsumen. ${ }^{49} \mathrm{Hal}$ ini bertentangan dengan Pasal 4 (c) Undang-Undang Nomor 8 Tahun 1999 tentang Perlindungan Konsumen, bahwa konsumen berhak atas informasi yang benar, jelas dan jujur mengenai kondisi dan jaminan barang dan/atau jasa.

Perjanjian pembiayaan antara perusahaan pembiayaan dan konsumen hanya menguntungkan pihak perusahaan tanpa memperdulikan konsumen. Pada prakteknya apabila konsumen tidak membayar selama tiga bulan, maka pihak perusahaan pembiayaan bisa mengambilnya secara paksa. Sebetulnya konsumen sudah menandatangani perjanjian dengan perusahaan pembiayaan itu sebagai pemilik sah barang tersebut, namun pembayarannya melalui kredit. Hal ini bertentangan dengan Pasal 18 ayat (1) huruf d Undang-Undang Nomor 8 Tahun 1999 tentang Perlindungan Konsumen, bahwa pelaku usaha dalam menawarkan barang atau jasa yang ditujukan untuk diperdagangkan dilarang mencantumkan klausula baku pada setiap dokumen atau perjanjian apabila menyatakan pemberian kuasa dari konsumen kepada pelaku usaha, baik secara langsung maupun tidak langsung untuk melakukan segala tindakan sepihak yang berkaitan dengan barang yang dibeli oleh konsumen secara angsuran. ${ }^{50}$

${ }^{48}$ El Zahra Aulia Faradita, Suharnoko, Perlindungan Hukum Terhadap Konsumen dalam Hal Eksekusi Jaminan Ditinjau dari Undang-Undang No. 8 Tabun 1999 Tentang Perlindungan Konsumen (Analisis Putusan No. 105/Pdt.G/2012/PN.Ska) dalam lib.ui.ac.id/naskahringkas/2016-05/S58005-El\%20Zahra\%20A, diakses 3Maret 2018.

\footnotetext{
${ }^{49}$ Juwita, Leasing..., Op. Cit., hlm. 12.

50 Ibid., hlm. 25.
} 
Kesepakatan bersama pembiayaan dengan penyerahan hak milik secara fidusia (perjanjian pembiayaan) juga disertai dengan surat kuasa pengikatan fidusia. Ketentuan ini bertentangan dengan Pasal 18 ayat (1) huruf h UndangUndang Nomor 8 Tahun 1999 tentang Perlindungan Konsumen yang menyatakan bahwa:

Pelaku usaha dalam menawarkan barang atau jasa yang ditujukan untuk diperdagangkan dilarang mencantumkan klausula baku pada setiap dokumen atau perjanjian apabila menyatakan bahwa konsumen memberi kuasa kepada pelaku usaha untuk pembebanan hak tanggungan, hak gadai, atau hak jaminan terhadap barang yang dibeli oleh konsumen secara angsuran.

Selain itu, perjanjian pembiayaan dibuat dengan menggunakan huruf yang sangat kecil dan harus ditandatangani oleh konsumen, sehingga konsumen tidak dapat membacanya secara jelas, dalam hal ini pelaku usaha telah melanggar Pasal 18 ayat (2) Undang-Undang Nomor 8 Tahun 1999. Apabila terjadi pelanggaran terhadap Pasal 18 Undang-Undang Nomor 8 Tahun 1999, maka pelaku usaha diancam dengan pidana penjara paling lama 5 tahun atau pidana denda paling banyak Rp. 2.000.000.000,00.

Oleh karena itu, perjanjian pembiayaan dengan penyerahan hak milik secara fidusia bila menggunankan form standar yang berisi syarat dan ketentuan yang menggunakan klausula baku yang bertentangan dengan Pasal 18 ayat (1) UndangUndang Perlindungan Konsumen mengakibatkan batal demi hukum.

Jika terjadi perselisihan antara konsumen dengan pelaku usaha sebetulnya ada Badan Penyelesaian Sengketa Konsumen (BPSK) yang dapat menjadi mediator antara kedua belah pihak, namun pada umumnya keberadaan badan ini belum banyak diketahui oleh konsumen. Keberadaan badan tersebut yang diketahui oleh lembaga pembiayaan tidak dimanfaatkan dan tidak diberitahukan oleh lembaga pembiayaan kepada konsumen, kemudian upaya menggugat lembaga pembiayaan oleh konsumen pun seolah-olah tidak mungkin dilakukan, karena terkendala biaya. 51

${ }^{51}$ Ibid., hlm. 30. 
Oleh karena itu terdapat beberapa hal yang harus diperhatikan ketika konsumen akan melakukan perjanjian kredit dengan lembaga pembiayaan, antara lain:52

1. Perjanjian akad kredit harus diakukan di hadapan notaris dan dihadiri oleh pihak konsumen dan lembaga pembiayaan.

2. Tidak menandatangani perjanjian yang telah dipersiapkan (klausula baku) yang telah dipersiapkan oleh lembaga pembiayaan yang bertentangan dengan Undang-Undang Nomor 8 Tahun 1999 Tentang Perlindungan Konsumen.

3. Memastikan bahwa akte perjanjian kredit yang dibuat notaris tersebutdidaftarkan di Kementerian Hukum dan Hak Asasi Manusia sebagaimana diatur dalam Undang-Undang Nomor 42 Tahun 1999 Tentang Jaminan Fidusia.

4. Memperoleh salinan akte notaris tersebut setelah didaftarkan di Kementerian Hukum dan Hak Asasi Manusia.

\section{Penutup}

Berdasarkan uraian di atas dapat disimpulkan bahwa, perlindungan hukum terhadap konsumen pada perjanjian fidusia yang tidak dibuat dengan akta notaris dan tidak didaftarkan di Kantor Pendaftaran Fidusia adalah bahwa pemberi fidusia dapat menggugat ganti rugi terhadap penerima fidusia atas dasar perbuatan melawan hukum sebagaimana diatur dalam Pasal 1365 Kitab Undang-Undang Hukum Perdata, karena apabila tidak didaftarkan tidak akan mendapatkan sertifikat Jaminan Fidusia dan penerima fidusia dalam melakukan eksekusi akan dianggap sepihak dan menimbulkan kesewenang-wenangan dari kreditur. Apalagi bila sebagian dari kewajiban dalam perjanjian tersebut telah dilaksanakan oleh pemberi fidusia, sehingga di atas benda jaminan tersebut terdapat sebagian hak milik pemberi fidusia dan sebagian hak milik penerima fidusia. Selain itu, tindakan sewenang-wenang yang dilakukan oleh kreditur melalui debt collector atau penagih hutang dapat dikatagorikan perbuatan yang melanggar hukum pidana, khususnya melanggar Pasal 368 KUH Pidana. Oleh karena itu jaminan fidusia harus didaftarkan di Kementerian Hukum dan Hak Asasi Manusia.

Ekseskusi jaminan fidusia tidak boleh melanggar asas perlindungan konsumen tentang keamanan dan keselamatan konsumen serta kepastian hukum 
sebagaimana diatur dalam Pasal 2 Undang-Undang Nomor 8 Tahun 1999. Di samping itu juga tidak boleh melanggar hak-hak konsumen sebagaimana diatur dalam Pasal 4 Undang-Undang Nomor 8 Tahun 1999 di mana konsumen berhak atas kenyamanan, keamanan dan keselamatan dalam mengkonsumsi barang dan jasa. Demikian pula perjanjian pembiyaan dengan penyerahan hak milik secara fidusia tidak boleh mencantumkan klausula baku yang bertentangan dengan Pasal 18 ayat (1) huruf d Undang-Undang Nomor 8 Tahun 1999, yaitu tidak boleh menyatakan pemberian kuasa dari konsumen kepada pelaku usaha, baik secara langsung maupun tidak langsung untuk melakukan segala tindakan sepihak yang berkaitan dengan barang yang dibeli oleh konsumen secara angsuran. Juga tidak boleh bertentangan dengan Pasal 18 ayat (1) huruf h Undag-Undang Nomor 8 Tahun 1999, yaitu dilarang mencantumkan klausula baku pada setiap dokumen atau perjanjian apabila menyatakan bahwa konsumen memberi kuasa kepada pelaku usaha untuk pembebanan hak tanggungan, hak gadai, atau hak jaminan terhadap barang yang dibeli oleh konsumen secara angsuran. Selain itu perjanjian pembiayaan tersebut harus dibuat dengan menggunakan huruf yang cukup besar, sehingga dapat dibaca secara jelas, tidak menggunakan huruf yang sangat kecil yang menyebabkan konsumen malas untuk membacanya.

Rekomendasi penelitian ini antara lain: diperlukan sosialisasi tentang pendaftaran jaminan fidusia, baik kepada pelaku usaha maupun kepada konsumen. Selain itu penggunaan klausula baku pada perjanjian pembiayaan dengan jaminan fidusia tentang pemberian kuasa dari konsumen kepada pelaku usaha, baik secara langsung maupun tidak langsung untuk melakukan segala tindakan sepihak yang berkaitan dengan barang yang dibeli oleh konsumen secara angsuran serta pernyataan konsumen memberi kuasa kepada pelaku usaha untuk pembebanan hak tanggungan, hak gadai, atau hak jaminan terhadap barang yang dibeli oleh konsumen secara angsuran harus ditinjau lagi dan disesuaikan dengan Undang-Undang Nomor 8 Tahun 1999, sehingga masih perlu sosialisasi serta BPSK diharapkan berperan aktif dalam penyelesaian sengketa antara konsumen dan pelaku usaha serta mengawasi pencantuman klausula baku yang dilarang, 
sehingga kepada pelaku usaha yang melanggar Pasal 18 Undang-Undang Perlindungan Konsumen dapat dikenakan sanksi yang tegas.

\section{Daftar Pustaka}

\section{Buku}

Barkatulah, Abdul Hakim, Hukum Perlindungan Konsumen Kajian Teoritis dan Perkembangan Pemikiran, Nusa Media, 2008.

Kamelo, H. Tan, Hukum Jaminan Fidusia Suatu Kebutuhan Yang Didambakan, Alumni, Bandung, 2006.

Miru, Ahmadi \& Sutarman Yodo, Hukum Perlindungan Konsumen, Raja Grafindo Persada, Jakarta, 2007.

Satrio, J., Hukum Jaminan Hak Jaminan Kebendaan, PT. Citra Aditya Bakti, Bandung, 2007.

Sidabalok, Janus, Hukum Perlindungan Konsumen di Indonesia, Citra Aditya Bakti, 2006.

Soekanto, Soerjono, Pengantar Penelitian Hukum, Universitas Indonesia Pers, Jakarta, 1986.

Soemitro, Ronny Hanitijo, Metodologi Penelitian Hukum dan Juritmetri, Ghalia Indonesia, Jakarta, 1990.

Sofwan, Sri Soedewi Mascjhoen, Beberapa Masalah Pelaksanaan Lembaga Jaminan Khususnya Fiducia di dalam Praktek dan Pelaksanaannya di Indonesia, Fakultas Hukum Universitas Gadjah Mada, Yogyakarta, 1977.

, Hukum Jaminan di Indonesia Pokok-Pokok Hukum Jaminan Perorangan, Liberty Offset, Yogyakarta.

Subekti, Jaminan-Jaminan untuk Pemberian Kredit Menurut Hukum Indonesia, Alumni, Bandung, 1982. , Pokok-Pokok Hukum Perdata, Intermasa, Jakarta, 1982.

Sumardjono, Maria S.W., Pedoman Pembuatan Usulan Penelitian, Fakultas Hukum UGM, Yogyakarta, 1989.

Widjaja, Gunawan \& Ahmad Yani, Jaminan Fidusia, PT. Raja Grafindo Persada, 2007.

\section{Jurnal}

Akhsin, Muhammad Hilmi, Anis Mashdurohatun, "Akibat Hukum Jaminan Fidusia Yang Tidak Didaftarkan Menurut UU Nomor 42 Tahun 1999", artikel dalam Jurnal Akta Vol. 4 No. 3 September 2017.

Ramadhani, Faranisa Yona, Muhamamad Fakih, Dita Febrianto, "Kedudukan Akta Otentik yang Dibuat oleh Notaris pada Pembuatan Akta Jaminan Fidusia", artikel dalam Pactum Law Journal, Volume 1 No. 1, 2017. 
Rizka, "Fidusia Dalam Lingkup Hukum Jaminan Dilihat Dari Sudut Pandangan Islam", artikel dalam Jurnal EduTech Vol. 2 No. 1 Maret 2016.

Setyorini, Arista, Agus Muwarto, "Akibat Hukum Perjanjian Pembiayaan Konsumen dengan Pembebanan Jaminan Fidusia yang Tidak Didaftarkan", artikel dalam Mimbar Keadilan Jurnal Ilmu Hukum, Agustus 2017.

Widyari, Ida Ayu Made, I Nyoman Sirtha, I Made Sarjana, "Akibat Hukum Pendaftaran Jaminan Fidusia Dalam Sistem Online", artikel dalam Acta Comitas (2017) 2.

\section{Internet}

El Zahra Aulia Faradita, Suharnoko, Perlindungan Hukum Terhadap Konsumen dalam Hal Eksekusi Jaminan Ditinjau dari Undang-Undang No. 8 Tahun 1999 Tentang Perlindungan Konsumen (Analisis Putusan No. 105/Pdt.G/2012/PN.Ska) dalam lib.ui.ac.id/naskahringkas/2016-05/S58005-El\%20Zahra\%20A, diakses 3 Maret 2018.

Juwita, Leasing Dalam Perspektif Perlindungan Konsumen Menurut Undang-Undang No. 8 Tahun 1999 Tentang Perlindungan Konsumen, jlps.iblam.ac.id/ index.php/jurnal-hukum-dan-kebijakan/../63byS.suardi.2016, diakses 3 Maret 2018.

\section{Peraturan Perundang-undangan}

Kitab Undang-Undang Hukum Pidana

Undang-Undang Nomor 8 Tahun 1999 tentang Perlindungan Konsumen

Undang-Undang Nomor 42 Tahun 1999 tentang Jaminan Fidusia

Peraturan Menteri Keuangan Nomor 130/PMK.010/2012 